\title{
COMPARATIVE EVALUATION OF SALIVARY INTERLEUKIN-8 LEVELS IN DIABETICS, HYPERTENSIVES AND SMOKERS WITH CHRONIC PERIODONTITIS
}

\author{
Sanjeev Jain ${ }^{1}$, Harjit Kaur ${ }^{2}$, Nisha Aggarwal ${ }^{3}$, Milli Gupta ${ }^{4}$, Divya Saxena ${ }^{5}$, Gaurav Pandav ${ }^{6}$ \\ ${ }^{1}$ Professor, Department of Periodontology, Guru Nanak Dev Dental College \& Research Institute, Punjab, India \\ ${ }^{2}$ Professor \& Head, Department of Periodontology, Guru Nanak Dev Dental College \& Research Institute, Punjab, India \\ ${ }^{3}$ PG Student, Department of Periodontology, Guru Nanak Dev Dental College \& Research Institute, Punjab, India \\ ${ }^{4}$ Sr. Lecturer, Department of Biochemistry, Harvansh Singh Judge Institute of Dental Sciences, Chandigarh, India \\ ${ }^{5}$ Sr. Lecturer, Department of Periodontology, Guru Nanak Dev Dental College \& Research Institute, Punjab, India \\ ${ }^{6}$ Sr. Lecturer, Department of Periodontology, Guru Nanak Dev Dental College \& Research Institute, Punjab, India
}

\begin{abstract}
\begin{tabular}{l|l} 
ABSTRACT \\
$\begin{array}{l}\text { Background: Cytokines are pivotal to the pathogenesis of periodontal disease and may be used as markers in } \\
\text { diagnosis. Systemic diseases and smoking are considered risk factors that have been associated with } \\
\text { periodontal disease progression. Cytokine production may also be influenced by smoking and systemic } \\
\text { diseases leading to an imbalance that disturbs the host-parasite relationship. Aim: The aim of the present } \\
\text { study was to determine and compare the levels of salivary IL-8 in diabetics, smokers and hypertensive } \\
\text { patients with chronic periodontitis. Materials and method: A total of } 80 \text { patients with chronic periodontitis } \\
\text { were included in the study. They were divided into four groups: } 20 \text { controls, } 20 \text { diabetics, } 20 \text { hypertensives } \\
\text { and } 20 \text { smokers. Unstimulated saliva samples were collected at first visit and IL-8 levels were measured by } \\
\text { enzyme linked immunosorbent assay (ELISA). Results: It was found that as compared to control group, } \\
\text { diabetic group presented with higher levels of IL-8 whereas hypertensive and smoker groups presented with } \\
\text { lower levels of IL-8. After statistical analysis it was found that this alteration was significant in smokers group } \\
\text { only. Conclusion: It can be concluded from the study that the levels of inflammatory biomarkers in chronic } \\
\text { periodontitis patients are altered with systemic factors. }\end{array}$
\end{tabular}
\end{abstract}
Key words: Chronic periodontitis, IL-8, Smoking, Hypertension, Diabetes, ELISA

\section{INTRODUCTION}

Saliva is said to be a "mirror of the body". It is an indicator of health not just in the oral cavity but throughout the body. It can be used to diagnose a wide range of conditions including periodontal, cardiovascular, autoimmune, endocrine, renal, infectious diseases and also in forensic studies. Human saliva harbors a repertoire of proteins, lipids, RNA, DNA, and some 700 microbial species. Researchers have been pursuing saliva as a biofluid for early disease detection and prognosis, risk stratification and monitoring treatment response. ${ }^{1}$

Several types of inflammatory dr.nishaaggarwal@gmail.com Received: $3^{\text {td }}$ Sept. 2014 Accepted: $40^{\text {th }}$ Oct. 2014 Online: $23^{\text {rd }}$ Jan. 2015 saliva such as IL-1 $\beta$, IL-6, IL-8, tumour necrosis factor- $\alpha$, MMP-8 and MMP-9. ${ }^{2}$ IL-8 is a chemokine important for PMN recruitment and also for PMN priming. It is secreted from different host cells including monocytes/macrophages, lymphocytes, fibroblasts, endothelial cells and epithelial cells. ${ }^{3}$

Given the important role of the PMN in periodontal homeostasis an altered or impaired PMN function may partially explain the increased susceptibility to periodontitis in diabetics. ${ }^{4}$ Individuals with diabetes mellitus have impaired neutrophil and macrophage function and altered collagen production in addition to exaggerated collagenase activity. This leads to the patient's heightened inflammatory state 
and interactions with advanced glycation end products (AGEs) have been shown to increase macrophage secretion of proinflammatory mediators. ${ }^{5}$

Hypertension is one of the major risk factors for cardiovascular diseases. Oxidative stress and endothelial dysfunction are among the critical components in the development of hypertension. Inflammation has received much attention recently and may play a pivotal role in hypertension. Periodontitis, a chronic low-grade inflammation of periodontal tissue, has been linked to endothelial dysfunction, with blood pressure elevation and increased mortality risk in hypertensive patients. Inflammatory biomarkers are increased in hypertensive patients with periodontitis. ${ }^{6}$

Smoking is harmful to almost every organ in the body and is the major risk factor for periodontitis. The cigarette smoking has been implicated in the activation of a complex inflammatory cascade resulting in the production of a variety of potent cytokines and chemokines, which in turn contribute to development of periodontal disease. ${ }^{7}$ Various studies have reported the possible role of IL-8 in GCF as a biomarker for periodontal disease but less literature is available on its role in saliva.

The aim of the present study was to determine and compare the levels of salivary IL- 8 in diabetics, smokers and hypertensive patients with chronic periodontitis.

\section{Materials}

The study group consisted of 80 patients, aged 35-50 years with chronic periodontitis and they were categorized into four groups: Group I- 20 controls, Group II- 20 diabetics, Group III-20 hypertensives, Group IV- 20 smokers.

\section{Inclusion criteria}

- Patients with chronic periodontitis having probing pocket depth of $4-6 \mathrm{~mm}$

\section{Exclusion criteria}

- Patients who had received oral prophylaxis within 6 months

- Patients who had received antibiotics and antiinflammatory drugs within 6 months.

- Pregnant females

\section{METHOD}

The clinical examination included assessment of probing pocket depth and gingival index GI (Loe and Silness 1963). All patients were informed of the study and consent was taken before the collection of the saliva sample. In order to avoid the possibility of contamination of saliva that could interfere with the immunoassay, the following instructions were given to the participants:

Do not eat a major meal within 60 minutes of sample collection.

Rinse mouth with water to remove food residue before sample collection, and swallow to increase hydration.

Wait at least 10 minutes after rinsing before collecting saliva to avoid sample dilution.

\section{Saliva collection}

After rinsing, patients were seated comfortably in the dental chair with eyes open and head tilted slightly forward. They were asked to minimize orofacial movements before commencing unstimulated saliva collection. Saliva was collected in the mouth while patient kept his/her lips closed. Spitting method given by Navazesh M in 1993 was used and the subjects were asked to expectorate in a sterile vessel. ${ }^{8}$

\section{Biomarker analysis}

The levels of IL-8 in the saliva were determined after centrifugal elution, by using commercially available enzyme-linked immunosorbent assays (ELISA). The assays were sandwiched (ELISAs) and performed according to the manufacturer's instructions using human recombinant standards. Results were calculated based on ELISA concentration values.

\section{STATISTICALANALYSIS}

The continuous data were presented as mean \pm standard deviation. Normality of quantitative data was checked by measures of Kolmogorov Smirnov tests of normality. Normally distributed Continuous variables between 4 groups were done by One-Way ANOVA followed by Post-Hoc Multiple comparisons. A $p$ value of $<0.05$ was considered to indicate statistical significance.

\section{RESULTS}

A total of 80 subjects in the age group of 35-50 years were selected and divided into four groups. The 
demographic and clinical data are summarized in Table 1. Table 2 shows the mean IL-8 levels in various groups. IL-8 levels in groups I, II, III and IV were $354.30 \pm 224.47,475.60 \pm 163.10,344.55 \pm 196.63$, $173.80 \pm 46.06(\mathrm{pg} / \mathrm{ml})$. Diabetic group (Group II) presented with higher levels of IL-8 whereas hypertensive group (Group III) and smoker group (Group IV) presented with lower levels of IL-8 as compared to control group (Group I). After statistical analysis it was found that this alteration was significant in smokers group only (Table 3 ).

Table 1: Demographic and clinical data of four different groups

\begin{tabular}{|l|c|c|c|c|}
\hline & $\begin{array}{c}\text { Group I } \\
\text { (control) }\end{array}$ & $\begin{array}{c}\text { Group II } \\
\text { (diabetic) }\end{array}$ & $\begin{array}{c}\text { Group III } \\
\text { (hypertensive) }\end{array}$ & $\begin{array}{c}\text { Group IV } \\
\text { (smokers) }\end{array}$ \\
\hline $\begin{array}{l}\text { Mean age } \\
\text { (years) }\end{array}$ & 42.9 & 44.3 & 46.5 & 38.4 \\
\hline $\begin{array}{l}\text { Mean } \\
\text { gingival } \\
\text { Index }\end{array}$ & 1.71 & 1.95 & 1.68 & 1.16 \\
\hline $\begin{array}{l}\text { Mean probing } \\
\text { pocket depth } \\
\text { (mm) }\end{array}$ & 4.87 & 5.08 & 4.47 & 4.04 \\
\hline
\end{tabular}

Table 2: Mean salivary IL-8 levels in four different groups

\begin{tabular}{|l|c|c|c|c|}
\hline & $\begin{array}{c}\text { Group } \\
\text { I }\end{array}$ & $\begin{array}{c}\text { Group } \\
\text { II }\end{array}$ & $\begin{array}{c}\text { Group } \\
\text { III }\end{array}$ & $\begin{array}{c}\text { Group } \\
\text { IV }\end{array}$ \\
\hline $\begin{array}{l}\text { Mean IL-8 levels } \\
(\mathrm{pg} / \mathrm{ml})\end{array}$ & 354.30 & 475.60 & 344.55 & 173.80 \\
\hline
\end{tabular}

Table 3: Intergroup comparison of mean salivary IL-8 levels

\begin{tabular}{|l|l|l|l|}
\hline Group & Mean \pm Std. Deviation & P value & Significance \\
\hline $\begin{array}{l}\text { Group I } \\
\text { Group II }\end{array}$ & $\begin{array}{l}354.30 \pm 224.47 \\
475.60 \pm 163.10\end{array}$ & 0.123 & $\mathrm{NS}$ \\
\hline $\begin{array}{l}\text { Group I } \\
\text { Group III }\end{array}$ & $354.30 \pm 224.47$ & 0.998 & $\mathrm{NS}$ \\
\hline $\begin{array}{l}\text { Group I } \\
\text { Group IV }\end{array}$ & $354.30 \pm 224.47$ & 0.007 & $\mathrm{HS}$ \\
\hline $\begin{array}{l}\text { Group II } \\
\text { Group III }\end{array}$ & $475.80 \pm 46.06 \pm 163.10$ & 0.083 & $\mathrm{NS}$ \\
\hline $\begin{array}{l}\text { Group II } \\
\text { Group IV }\end{array}$ & $\begin{array}{l}475.60 \pm 16.03 \\
173.80 \pm 46.06\end{array}$ & $<0.001$ & $\mathrm{HS}$ \\
\hline $\begin{array}{l}\text { Group III } \\
\text { Group IV }\end{array}$ & $344.55 \pm 196.63$ & 0.012 & $\mathrm{~S}$ \\
\hline
\end{tabular}

\section{DISCUSSION}

The ability to monitor health status, disease onset, progression and treatment outcome through noninvasive means is a highly desirable goal in health care promotion and delivery. Saliva is a perfect medium to be explored for health and disease surveillance. The multifactorial components within saliva not only protect the integrity of the oral tissues, but also provide clues to local and systemic diseases and conditions. The salivary biomarkers are being explored as a means of monitoring general health and in the early diagnosis of disease. ${ }^{9}$ Saliva clearly meets the demands for an inexpensive, noninvasive, and easy-touse screening method. Saliva has many advantages in terms of collection, storage, shipping and voluminous sampling.

The present study examined the levels of IL-8 in saliva of four different groups. IL- 8 was detected in saliva in all the groups. IL- 8 could also be detected in the sites of healthy gingiva. Since a small number of macrophages and neutrophils can be found in clinically normal tissues. This could be related to the steady state of gingiva, considering that gingival sulcus is a site of permanent antigenic insult requiring the presence of neutrophils, macrophages and antigen presenting cells, which could be chemoattracted towards the gingival microenvironment by IL- 8 . It is highly important in the initiation and development of inflammatory response and tissue destruction in periodontal diseases due to its critical role in recruitment and functional activation of neutrophilic granulocytes. It induces change in shape of neutrophils resulting in pavementing and diapedesis; promotes chemotaxis, and causes a rise in intracellular free calcium, potentiating the respiratory burst and exocytosis of primary and secondary granules from these cells. ${ }^{11}$

According to Tsai C et al (2002), individuals with diabetes mellitus (DM) have greater incidence and severity of periodontal disease than individuals without DM of similar age. ${ }^{12}$ In diabetes polymorphonuclear neutrophil (PMN) chemotaxis, phagocytosis, oxidative burst and killing ability is altered. Hyperglycemia leads to increased PMN superoxide production and oxidative stress in the diabetic state may augment existing chronic inflammatory diseases such as periodontitis. ${ }^{4}$ The reasons for poor glycemic control among patients with unsatisfactory periodontal health could be explained by roles played by periodontal bacteria and monocyte-macrophage cells.

The monocyte-macrophage cell may be hyperresponsive to bacterial antigens in people with diabetes, resulting in significantly increased local production of pro-inflammatory cytokines and mediators, which in turn have been shown to exert a great impact on glycemic metabolism through systemic 
circulation. ${ }^{13}$ In the present study, IL-8 levels were found to be highest among the diabetic group as compared to other groups. But after statistical analysis, it was observed to be significantly higher in smoker group. The studies conducted by Zozulinska $\mathrm{D}$ et al (1999) and Herder C et al (2005) showed higher IL-8 levels in subjects with diabetes as compared to controls. ${ }^{14,15}$ In contrast, Engebreston SP et al (2006) found lower levels of IL- 8 in the GCF of diabetic patients. According to them, an inadequate local response by PMN, partially explained by an altered chemokine gradient, may contribute to periodontal disease in patients with type 2 diabetes mellitus. ${ }^{4}$

Hypertension and periodontitis share common risk factors i.e. smoking, stress, increased age, and socioeconomic factors. Dental biofilms release a variety of biologically active products including bacterial lipopolysaccharides, chemotactic peptides, protein toxins, and organic acids. Production and release of proinflammatory prostaglandins and cytokines such as interleukin-1 beta (IL-1 $\beta$ ), interleukin-6 (IL-6), interleukin-8 (IL-8), and tumour necrosis factor-alpha (TNF- $\alpha)$ are triggered in response to stimuli of dental biofilms. The active products by biofilms and host responses are responsible for periodontal tissue destruction. The released products may also affect various disease pathways such as atherosclerosis and mucosal inflammation. Increased leukocytes infiltration and production of cytokines exaggerate oxidative stress and inflammation, eventually causing a disturbance to the normal endothelial function in regulating blood pressure. ${ }^{6}$

In this study IL-8 levels in hypertensive group were lower as compared to control group and diabetic group but this was not found to be statistically significant. But IL-8 levels in hypertensive group were significantly higher when compared to smokers.

The effect of smoking on cytokines production in periodontal patients has been extensively investigated and conflicting results have been reported. In the present study the levels of IL-8 were significantly lower in smoker group as compared to other groups. This is in accordance with Sher ME et al (1999) who showed negative correlations between IL-8 levels and smoking. ${ }^{16}$ Fredriksson $M$ et al (2002) found that smoking reduces the sensitivity of peripheral neutrophils to stimulation by IL- $8 .{ }^{17}$ This suggests that smoking may interfere with the inflammatory process by affecting the release of pro-inflammatory cytokines. Radek KA et al (2010) found that exposure to nicotine suppresses the innate immune response to infection by reducing the activity of antimicrobial peptides. It is possible that a similar phenomenon may occur with the production of chemokines and cytokines in smokers. Tymkiw KD et al (2011) showed decreased amounts of proinflammatory cytokines and chemokines in smokers. ${ }^{19}$ Whereas Moi $\mathrm{T}$ et al (1997) reported increased secretion of IL-8 in smoker periodontitis patients. ${ }^{20}$ Giannopoulou C et al (2003) showed positive associations between smoking and total amounts of GCF IL-8, IL-6 and IL-4 but not with the level of IL$1 \beta .^{21}$ According to Ghurabi BHA et al (2013) elevation of serum IL-1 $\beta$, IL-8 and IL-17 levels among smokers could be due to response to LPS of gram negative bacteria. $^{7}$ Rathnayake N et al (2013) showed positive associations of various salivary biomarkers with systemic diseases like diabetes, cardiac, bowel, muscle and joint diseases. ${ }^{2}$

Quantifiable biomarker assessment could lead to more sensitive, accurate and rapid measures of oral health status in varying patient populations in addition to those of the more subjective clinical indices. With advances in microbiology, immunology and biochemistry, salivary testing in clinical and research settings is rapidly proving to be a practical and reliable means of recognizing oral signs of systemic illness and exposure to risk factors.

\section{CONCLUSION}

It can be concluded from the study that the levels of inflammatory biomarkers in chronic periodontitis patients are altered with systemic factors. Saliva-based clinical testing could provide a potential diagnostic tool for the detection of biomarkers associated with enhanced systemic inflammation. Saliva based diagnostics provide great opportunities for research and also have the potential to become important components of routine health monitoring and early detection of diseases.

\section{REFERENCES}

1. Punyadeera C. Saliva. Clinical Laboratory News 2013;39(1).

2. Rathnayake N, Åkerman S, Klinge B, Lundegren N, Jansson H. Salivary Biomarkers for Detection of Systemic Diseases. PLoS One. 2013; 8(4). 
3. Erdemir EO, Baran I, Nalcaci R, ApanT. IL-6 and IL-8 levels in GCF of the teeth supporting fixed partial denture. Oral Diseases 2010;16(1):83-88.

4. Engebretson SP, Vossughi F, Hey-Hadavi J, Emingil G, Grbic JT. The influence of diabetes on gingival crevicular fluid bglucuronidase and interleukin-8. J Clin periodontol 2006;33: 784-790.

5. Salvi GE, Franco LM, Braun TM, Lee A, Rutger Persson G, Lang NP, Giannobile WV. Pro-inflammatory biomarkers during experimental gingivitis in patients with type 1 diabetes mellitus: a proof-of-concept study. J Clin Periodontol 2010;37:9-16.

6. Leong XF, Ng CY, Badiah B, Das S. Association between Hypertension and Periodontitis: Possible Mechanisms. ScientificWorldJournal. 2014;2014;(768237)

7. Ghurabi BH Al. Impact of Smoking On The IL-1 $\beta$, IL-8, IL10, IL-17 And TNF- $\alpha$ Production In Chronic Periodontitis Patients. Journal of Asian Scientific Research, 2013, 3(5):462470.

8. Navazesh M. Methods for collecting saliva. Ann N Y Acad Sci.1993;694:72-77.

9. Lawrence HP. Salivary Markers of Systemic Disease:Noninvasive Diagnosis of Disease and Monitoring of General Health. J Can Dent Assoc 2002;68(3):170-4.

10. Lee YH, Wong DT. Saliva: an emerging biofluid for early detection of diseases. Am J Dent 2009;22(4):241-248

11. Paul AM, Victor DJ, Prakash PSG. Role of Interleukin-8 in Periodontal Disease. IJCDS. 2012;3(2):32-38.

12. Tsai C, Hayes C, Taylor GW. Glycemic control of type 2 diabetes and severe periodontal disease in the US adult population. Community Dent Oral Epidemiol 2002; 30:182-92

13. Chen L, Wei B, Li J, Liu F, Xuan D, Xie B, Zhang J. Association of periodontal parameters with metabolic level, systemic inflammatory markers in type 2 diabetes patients. J Periodontal 2010;81(3):364-371.
14. Zozulinska, D., Majchrzak, A., Sobieska, M., Wiktorowicz, K. \& Wierusz-Wysocka, B. Serum interleukin-8 level is increased in diabetic patients. Diabetologia. 1999;42(1):1178 .

15. Herder C, Haastert B, Müller-Scholze S, Koenig W, Thorand B, Holle R, Wichmann HE, Scherbaum WA, Martin S, Kolb H. Association of systemic chemokine concentrations with impaired glucose tolerance and type 2 diabetes: results from the Cooperative Health Research in the Region of Augsburg Survey S4 (KORA S4). Diabetes. 2005;54(2).

16. Sher ME, Bank S, Greenberg R, Sardinha TC, Weissman S, Bailey B, Gilliland R, Wexner SD. The influence of cigarette smoking on cytokine levels in patients with inflammatory bowel disease. Inflamm Bowel Dis. 1999;5(2):73-8.

17. Fredriksson, M., J. Bergström and B. Åsman. IL-8 and TNF- $\alpha$ from peripheral neutrophils and acute -phase proteins in periodontitis. Effect of cigarette smoking: A pilot study. J Clin Periodontology 2002;29:123-128.

18. Radek KA, Elias PM, Taupenot L, Mahata SK, O'Connor DT, Gallo RL. Neuroendocrine nicotinic receptor activation increases susceptibility to bacterial infections by suppressing antimicrobial peptide production. Cell Host Microbe. 2010; 22;7(4):277-89.

19. Tymkiw KD, Thunell DH, Johnson GK, Joly S, Burnell KK, Cavanaugh JE, Brogden KA, Guthmiller JM. Influence of smoking on gingival crevicular fluid cytokines in severe chronic periodontitis. J Clin Periodontol 2011;38:219-228.

20. Moi, T., D.J. Romberger, A.B. Thompson, R.A. Robbins, A Heires and S.I. Rennard. Cigarette smoke induces interleukin8 release from human bronchial epithelial cells. American J of Respiratory and Critical Care Medicine 1997;155:1770-1776.

21. Giannopoulou C, Kamma JJ, Mombelli A. Effect of inflammation, smoking and stress on gingival crevicular fluid cytokine level. J Clin Periodontol 2003;30:145-15 